DOI https://doi.org/10.30525/978-9934-26-146-6-29

\title{
ФОРМУВАННЯ КУЛЬТУРИ ЗДОРОВ'Я ЯК ПЕРЕДУМОВА ВИБОРУ ЗДОРОВОГО СПОСОБУ ЖИТТЯ
}

\author{
Лаврова Л. В. \\ кандидат філософських наук, доцент, \\ завідувач кафедри виховання та культури здоров'я \\ КЗВО «Дніпровська академія неперервної освіти» \\ Савченко В. А. \\ кандидат педагогічних наук, доцент, \\ доиент кафедри виховання та культури здоров'я \\ КЗВО «Дніпровська академія неперервної освіти»
}

Андрющенко Т. Г.

старший викладач кафедри виховання та культури здоров'я КЗВО «Дніпровська академія неперервної освіти» м. Дніпро, Украӥна

Під культурою здоров'я можна прийняти духовні і соціальні досягнення поколінь, спрямовані на підтримку і зміцнення особистого i суспільного здоров'я, на духовно-моральний розвиток людини, на реалізацію їі потенційних здібностей і задатків в інтересах загального блага. Коли ми говоримо про культуру здоров'я, то маємо на увазі, що в це змістовне поняття треба включати не тільки обсяг знань про сутність людини і іiі взаємодію 3 навколишнім світом, але і формування мотивів до прагнення бути здоровим, формування відповідної значеннєвої сфери діяльності, корисних і потрібних звичок і стереотипів поводження, уміння орієнтуватися в інформаційних потоках. Весь спектр перелічених складових культури здоров'я може бути реалізований лише у освітній діяльності в результаті цілеспрямованого формування компетенцій особистості щодо свого здоров'я та здорового способу життя [5, с. 29]. Культура здоров'я показує відображення впливу на здоров'я соціальних умов та системи освіти у вигляді сформованих ціннісних орієнтацій іншими словами, яке місце цінність здоров'я займає на шкалі суспільства, групи, окремої особистості, у вигляді культурних традицій, стереотипів, моделей поведінки, пов'язаних з питаннями здоров'я.

Культура здоров'я як один 3 життєзабезпечуючих компонентів існування людини може бути визначена як сукупність знань, цінностей, норм, ідеалів, установок, пов'язаних з уявленнями про здоров'я як цінності, що виконують регулятивну роль і орієнтують функції відносно 
тих видів діяльності, які забезпечують формування, підтримку й зміцнення здоров'я [3, с. 18]. Культура здоров'я містить у собі потреби й здатність індивіда до максимальної самоактуалізації в якості соціально й індивідуально-значимого суб'єкта на основі використання можливостей, наданих природою і перетворених цілями й принципами культуродоцільності.

Найважливішим елементом культури здоров'я є ставлення суб'єкта до свого здоров'я. Відповідальне ставлення до здоров'я є значимим і на соціальному, i на особистісному рівні. У суспільстві все більше утверджуються уявлення, згідно з якими відповідальність за здоров'я людини значною мірою несе вона сама, вона формується як частина загальнокультурного й індивідуального розвитку й проявляється в здатності побудувати себе як особистість відповідно до власних уявлень про повноцінне життя. Саме у цьому контексті - як проблему ставлення особистості до власного здоров'я - і розглядають взаємодію культури здоров'я та здорового способу життя більшість дослідників

Історично склалося так, що культура здоров'я формувалася, насамперед, під впливом практичних потреб суспільства. А соціальні функції здорового способу життя реалізуються через активну діяльність людини, спрямовану на використання відповідних культурних цінностей. Результатом діяльності щодо формування культури здоров'я $\epsilon$ формування цінностей та знань, необхідних для забезпечення здорової життєдіяльності. Що стосується здорового способу життя, то він через систему освіти і виховання, спираючись на наявну культуру здоров'я, безпосередньо визначає форми та зміст здорової життєдіяльності [4, с. 38].

Звідси випливає, що здоровий спосіб життя слід розглядати як особливий різновидність культурної діяльності, результати якої корисні для суспільства й особистості. У житті особистості та суспільства, у системі освіти, у сфері організації праці, повсякденного побуту, відпочинку здоровий спосіб життя проявляє своє виховне, освітне, оздоровче, економічне й загальнокультурне значення як безпосередній чинник моделей поведінки та діяльності, що забезпечують здоров'я суспільства та особистості.

Культура здоров'я у здоровому способі життя проявляється передусім як різноманіття його цінностей, трансльовані системою освіти. Цінності культури здоров'я представляють собою цілі, норми, правила, уявлення, що регламентують освітньо-виховну практику в суспільстві по формуванню особистості, що володіє розвиненим рівнем культури здоров'я, у свою чергу інтегрованої в її загальнокультурний розвиток i необхідної для виконання піi соціальних ролей i самоорганізації здорової життєдіяльності. 
Культура здоров'я людини - це не тільки інтегральна якість особистості, діалектично зв'язана з її загальною культурою, але й спосіб життя, що $\epsilon$ діяльнісною стороною культури здоров'я особистості. Культура здоров'я людини відбиває сформованість особистісного ідеалу, відповідно до якого духовний, психічний i фізичний аспекти здоров'я $\epsilon$ вищою загальнолюдською цінністю. Досягнення цього ідеалу можливо тільки лише через практичне здійснення здорового способу життя.

Людина сприймає суспільні норми здорового способу життя через культуру здоров'я, переважно у межах освітнього процесу, де вони інтеріоризуються нею як особистісно значущі, однак вони не завжди збігаються із цінностями, виробленими в масовій культурі. Якщо відповідальне ставлення до здоров'я задає загальне позитивне тло сприйняття особистістю усього комплексу питань, пов'язаних зі збереженням і розвитком здоров'я, то здійснення здорового способу життя відображає активний компонент культури здоров'я, що забезпечує перехід знань, установок, цінностей, пов'язаних зі здоров'ям, у практичну діяльність по досягненню оптимуму стану здоров'я в межах власної життєдіяльності [1, с. 274]. Відтак можна виділити структуру культури здоров'я, які містять основні універсальні елементи готовності до здорового способу життя, які мають слугувати змістовною основою формування культури здоров'я особистості у освітньому процесі. До таких елементів доцільно віднести:

- сформовану систему знань про здоровий спосіб життя;

- розвиток ціннісний уявлень про здоровий спосіб життя;

- встановлені соціальні та особистісні потреби в сфері здорового способу життя;

- бажання реалізувати всі компоненти здорового способу життя;

- конкретизована мотивація досягнення здорового способу життя;

- наявність умінь для реалізації здорового способу життя;

- практичні дії для досягнення здорового способу життя.

Формування культури здоров'я у процесі освітньої діяльності має також передбачати певну діяльність 3 активізації резервних можливостей організму на основі формуванню в особистості відчуття нерозривного зв'язку з соціальним та природним оточенням, потреби у духовному розвитку та самоактуалізації [2, с. 197]. У цьому більш загальному духовно-ціннісному контексті здоровий спосіб життя має спиратися на наступні аспекти культури здоров'я:

- перехід особистості на позитивну картину світу, включаючи оптимістичну оцінку свого положення в ньому;

- побудова оптимістичної життєвої перспективи особистісного розвитку; 
- оптимізація своєї взаємодії з навколишнім середовищем у межах повсякденної життєдіяльності;

- розширення уявлень про можливості свого організму, як фізичні, так і духовні;

- оволодіння методиками особистісної саморегуляції;

- цілеспрямоване оволодіння знаннями, уміннями й навичками в сфері здоров'я;

- регулярні заняття фізичною підготовкою.

Таким чином, наявність культури здоров'я дозволяє особистості вибудувати свою життєдіяльність на найбільш сприятливому для себе рівні у вигляді здорового способу життя. Опираючись на ключові положення гуманістичного підходу, згідно з яким пріоритети віддаються особистості, іiі інтересам, розвитку, формування культури здоров'я і на іiі основі - здорового способу життя може розглядатися в якості одного 3 орієнтирів освітньої діяльності.

\section{Література:}

1. Волошко Н. І. Психологія становлення здорового способу життя учасників навчально-виховного процесу: монографія. Київ : Логос, $2015.414 \mathrm{c}$.

2. Здоров'язбережувальні технології в освітньому середовищі: колект. монографія / [Т. К. Андрющенко та ін.] ; за заг. ред. д-ра пед. наук Л. М. Рибалко. - Тернопіль : Осадца В. М., 2019. 399 с.

3. Навички заради здоров'я: Навчання здоровому способу життя на засадах розвитку навичок: важливий компонент школи, дружньої до дитини, школи, що підтримує здоров'я. Київ : ЮНІСЕФ в Україні, 2004. $123 \mathrm{c}$.

4. Соціально-психологічні основи здоров'язберігаючих технологій: [колект. монографія] / I. А. Бурлакова [та ін.] ; [під наук. ред. Н. С. Завацької]. Сєвєродонецьк : Вид-во СНУ ім. В. Даля, 2018. 403 с.

5. Формування здорового способу життя молоді : навч.-метод. рек. / [Т. Андріученко (керівник) та ін.]. Київ : Бланк-Прес, 2019. 119 с. 